\title{
Exploring the Salutogenic University: Searching for the Triple Point for the Becoming-Caring-Teacher Through Collaborative Cartography
}

Ian M. Kinchin ${ }^{1}$, Cathrine Derham ${ }^{2}$, Charlotte Foreman ${ }^{3}$, Anna McNamara ${ }^{4}$, Dawn Querstret ${ }^{5}$

\footnotetext{
1 Surrey University, Institute of Education, Guildford, GU2 7XH, UK, i.kinchin@surrey.ac.uk

2 Surrey University, Faculty of Health and Medical Sciences, Guildford, GU2 7XH, UK, c.derham@surrey.ac.uk

3 Surrey University, Faculty of Engineering and Physical Sciences, Guildford, GU2 7XH, UK, c.foreman@surrey.ac.uk Surrey University, Guildford School of Acting, Guildford, GU2 7XH, UK, a.m.mcnamara@gsa.surrey.ac.uk

St. Mary’s University, Faculty of Health, Sport and Applied Science, Twickenham, TW1 4SX, UK, dawn.querstret@ stmarys.ac.uk
}

Annotation. This paper offers a perspective on 'care' as a component in the identity of successful university teachers. Three key lines of flight within this assemblage (care, pedagogic health, and salutogenesis) are examined here. In combination, they may offer a response to hegemonic neoliberal discourses that typically divert academics from enacting their professional values. A 'triple point' is hypothesised, at which the three lines would be found to co-exist, without border or barriers.

Keywords: assemblage, becoming, care, currere, pedagogic health, rhizome, salutogenesis.

\section{Introduction}

The current literature in Higher Education is overflowing with negative commentaries about the neoliberal forces that are driving universities away from the professional values that many academics hold dear, in favour of market-driven, political directives that place institutions as corporations rather than centres of higher learning. These critiques extend from the level of national policy, such as the Teaching Excellence Framework (in 
the UK) that is seen by Tomlinson et al $(2018,1)$ 'as an instrument for the entrenchment and amplification of neo-liberal market competition', to the more personal 'mundane moments' that 'cause cumulative harm and hurt' to individual academics (Taylor et al., 2020, 8). It may be important to highlight these issues in the literature by 'pumping out furious articles', as described by Manathunga \& Bottrell $(2019,9)$, as these issues are likely to be behind systems that exhibit pedagogic frailty (Kinchin and Winstone, 2017). However, the continual pathologizing of the university does not appear to have exerted a positive influence on practice, and it may be that regular attacks on the vague concept of neoliberalism may, in some instances, have become reduced to the level of 'ritualistic denouncements' (Tight, 2019, 279) rather than critical commentaries. In an attempt to escape from the pathologizing discourses of Higher Education in which emphasis is on remediation of deficits, this paper aims to offer an alternative viewpoint by adopting a non-linear, rhizomatic exploration of the salutogenic university, by drawing on the work of Antonovsky (1987) that has been contextualised by Kinchin (2019).

Rhizomatics is a philosophical position created around the non-linear figuration of the rhizome (Deleuze and Guattari, 1987) as a reaction against the predominantly linear thought processes, described as 'tree thinking' or 'arborescent thinking'. This linear tree thinking has driven higher education along a detrimental, neoliberal route, and has been observed to be 'detracting from the knowledge project that was once the central function of universities' (Charteris et al., 2016, 32), by providing simplistic 'causal relations that policymakers and others have assumed exist between students and test, teaching and learning.' (Strom and Martin, 2017, 5). The rhizomatic exploration of the salutogenic university (Kinchin, 2019) seeks to cultivate 'brave spaces' to engage in challenging dialogues (sensu Arao and Clemens, 2013), and to face up to the dominant culture in Higher Education: Resisting the flows of neoliberalism is different from past struggles. For now, it also encompasses resisting our own practices, it is about confronting oneself at the centre of our discomforts.

(Ball and Olmedo, 2013, 93)

In adopting a rhizomatic perspective we have to accept there is no linear developmental 'track' for colleagues to follow with arbitrary end-points for 'assessment', or professional standards to which they should align - in the sense typically understood as 'curriculum'. Rather, the autobiographical writings that are encouraged here reflect a 'migratory practice' that does not have a shared place of departure or a set destination. It supports development 'lived-as-migrancy, one in constant transit, of departing, returning, thinking back and writing forward' (Ng-A-Fook, 2005, 55). As such, this perspective resonates with the concept of 'currere', as a verb ('to run'), and 'reconceptualises curriculum from course objectives and outcomes to complicated conversation' (Pinar, 2019, 26). Critically, this moves our attention 'from what constitutes the course of education towards recognising education as coursing' (Sellers, 2008, 53). This is particularly important for experienced academics who are not engaged in formal programmes of development (that are often 
only targeted at new entrants to the profession), and to help focus the informal practices that contribute to teacher development (e.g. Mårtensson and Roxå, 2015; McCune, 2018), and the range of knowledges (academic and experiential knowledge) they employ in the development of their practice (e.g. Santos, 2014).

\section{Methodological approach}

We have adopted Deleuzian mapping as a method to research university teachers' professional practice and experience. This theoretical and methodological framing acknowledges that the research and the researchers are relationally intertwined and mutually constituted (sensu Aronsson \& Lenz Taguchi, 2018). As the map under construction is a moving construction of converging and diverging lines and their connected practices, we need to acknowledge that a Deleuzian (or Deleuzo-Guattarian)-inspired cartographic exercise is not about representing a final goal structure, but rather it is about constructing a map as a field of play to experiment on (Lenz Taguchi, 2016). The purpose of this article is to offer a conception of university teachers' experiences of 'becoming-teacher' (sensu Strom and Martin, 2017; Adams, 2021) as part of their 'lived professional space' (Vilma \& Marius, 2020). But more than this, we are interested in the conception of 'becoming-caring-teacher in the salutogenic university' (Kinchin, 2019). Borrowing from Cristancho and Fenwick (2015), we are interested in investigating the complexities of professional practice in which 'knowing' is inseparable from the activity and materials of practice, and where 'becoming' has no endpoint:

In contrast to notions of rugged individuals who achieve definitive status as experts, 'becoming' is a continuous emergent condition. It is often a process of struggle, and is always interminably linked to its environs and relationships (p. 128).

Therefore, "a process of cartography [is] preoccupied with both tracing and mapping by laying out the lines (both the [molar] articulating lines and lines of flight) ... forming a complex rhizome" (Lenz Taguchi, 2016, 42). In considering the contributions by each of the participants in this work, we acknowledge the comments offered by Gannon et al. $(2014,184)$ in guiding our considerations:

Close attention to specific sensory, affective, and embodied detail is crucial to this type of writing. The processes of collective biography produce embodied accounts of being; each subject's moments of singular sensation and memory are opened up so that they begin to resonate with the memories and embodied accounts of becoming of other members of the research group. In this approach, memories are not merely assemblages of familiar stories, narrated by and about essential and individualized selves; they become data for collective inquiry into processes of subjectification. The observations, questions, and comments that are provoked by each memory-story are crucial to the 
process of opening these texts to alternative readings and subsequent rewritings (p. 184).

In their analysis of the professional development of surgeons, Cristancho and Fenwick (2015) focused on three elements of professional becoming, looking for the ways in which different factors interact and develop. We are attempting to go a stage further here in our analysis, exploring the idea that under certain conditions the three lines will coalesce and become temporarily indistinguishable - forming a 'triple point' (Kinchin, 2019). Triple points mark conditions at which three different phases (or states) can coexist. For example, in Chemistry water has a triple point corresponding to the single temperature and pressure at which solid, liquid, and gaseous water can coexist in a stable equilibrium. This is seen by DeLanda (2016) as an example of a Deleuzian assemblage. The analogy of the triple point in education has been used to positive effect by Chemist, Penny Gilmer (Gilmer, 2002), to consider three conflicting aspects of her professional identity: research, teaching, and service. She found the analogy energising, and stated:

When you think of a triple point, consider the release of energy that occurs in an actual phase transition... I can tap into my triple point as a seemingly infinite source of energy. This energy empowers me to be the person I want to be and to act in multiple domains, to reconceptualize myself in the act of actualizing (p. 430).

For Gilmer, the identification of her triple point had a constructive impact on her wellbeing. It is suggested here that it might be empowering if academics were able to identify their own personal triple points, helping them to articulate their personal values as a force to counter the hegemony of neoliberal managerial discourses that have been accused of 'crushing the lifeblood of inspiration out of academe' (Manathunga and Bottrell, 2019, 1). Coming from a different perspective, Gannon et al $(2019,49)$ refer to 'micro-moments where different atmospheres emerged, where energy was released, where cracks opened and something else was let in'. These are seen as moments of 'positive affect' that take place 'in the interstices of everyday routines'. We are working under the assumption here that the act of revealing and articulating this cartography represents a starting point for professional development through promoting enhanced agency. As stated by Charteris et al (2016):

The cartographies of academic spaces are tense and precarious, dependent upon hierarchies of power and voice. Yet, recognising and unthreading the perturbations and impasses that we face in the present makes re-threading alternative conditions possible (p. 24).

The precarious nature of these cartographies and their dependence upon the wider contexts in which they operate could mean that rather than offering 'empowerment', realisation of the triple point (or a realisation of the impossibility of its attainment in a particular environment) could be disempowering. This is explored here. 


\section{Participant biographies}

Each of the four participating disciplinary academics (Cathy, Charlotte, Anna, and Dawn) had recently contributed chapters to collections that were edited by the first author (Ian). These outputs had offered detailed personal insights into the individual teaching philosophies enacted by each of the four academics and provided the starting points for discussions about the nature of care within their teaching contexts. Dawn (Querstret, 2019) had authored a chapter that looked specifically at ways to collaborate with students to support their wellbeing. This chapter had identified perceptions of the need for care as a key factor in students seeking help. Anna (McNamara, 2018) and Cathy (Derham, 2018) had written personal, self-reflective chapters that had examined their own practice in the context of pedagogic frailty. The editors' commentary on Cathy's chapter noted that for her "teaching was synonymous with caring". In addition, Cathy (Panzieri \& Derham, 2020), Charlotte (Eslahi et al., 2020; Foreman et al., 2020) and Anna (Hanratty \& McNamara, 2020) had all been at the forefront of a university-wide initiative to encourage student-staff research partnerships. This required a significant commitment by the authors and presented a potential risk in working alongside a student on a project whose success was not guaranteed at the outset. Collectively, these detailed written insights to the four co-authors' caring conceptions of teaching, along with the lead author's knowledge of their participation in various committees, working groups, research projects and other student-focused initiatives on the campus provide a considerable body of evidence to suppose that these colleagues are indeed caring teachers. This is justification for their selection as exemplars for this study. What was not clear at the outset was how this would manifest itself in different ways for colleagues working across different disciplines and in different roles, or whether these colleagues had taken time to reflect on this aspect of their practice.

DeLanda (2006) acknowledges the difficulties posed by trying to develop a visual representation of complex assemblages (such as teaching), and so refers to the 'virtual diagrams' that can be developed using the language of the lines to provide rich descriptions of the flows and interactions exhibited. However, as a support for an exploratory interview/dialogue, this does not provide a simple, clear prompt for discussion. To support the discussions featured in this paper, a simple heuristic was devised to summarise the key characteristics of the three lines of flight (care, pedagogic health, and salutogenesis) as a visual aide memoire (Figure 1). In Deleuzian terms, Figure 1 may be seen as a tracing to be placed over the emerging map of the participants' dialogues so that "tracing and mapping together can make a diagram visible" (Zdebik, 2012, 12). The first author's role here was to tease out these personal maps:

As a researcher, you trace and put onto your constructed map some of the intensive chattering of various loud and dominant (molar) lines of articulation, in terms of thinking, talking, and practicing particular ways of knowing. You observe how different forms of chatter harmonize, converge and stretch their 
root threads into stronger circles of convergence. Other intensive chattering might instead stretch out towards other circles or make offshoots in completely other directions to become deterritorialized. These are the lines of flight: the escaping forces away from those articulating molar lines. (Lenz Taguchi, 2016, 43).

As reflective and caring practitioners, it was anticipated that the authors would offer some challenge to the limiting factors acting on their development as university teachers. As such they would, perhaps, indicate possible lines of flight that would counter the neoliberal dominance of higher education discourse, and disrupt the status quo. If not, then the circles of convergence of the molar lines are likely to strengthen their grip on the teaching agenda, making any disruption of the system less likely.

Figure 1

Triple Point Discovery Wheel

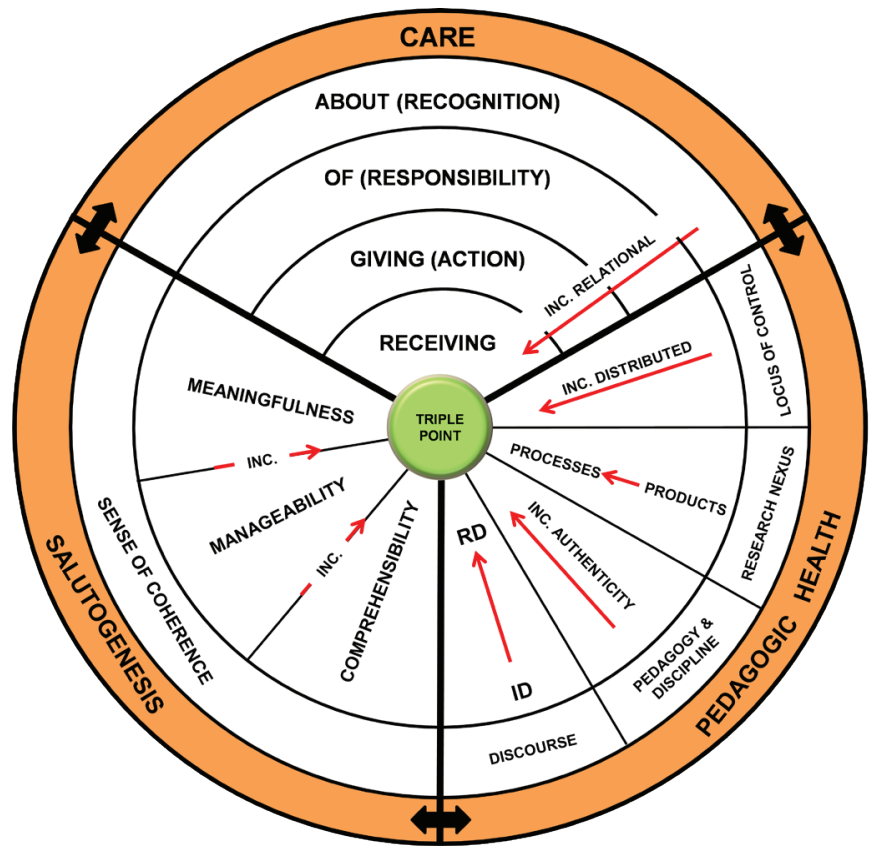

Note. $\mathbf{R D}=$ Regulative Discourse that relates to the fundamental factors that underpin pedagogy and includes theories, beliefs and values, ID = Instructional Discourse that relates to the day-to-day mechanics of teaching and includes timetabling, staffing, budgeting etc. INC. = Increasing[ly]. (This draws on the detailed description of these three lines of flight within the salutogenic university, described by Kinchin, 2019).

None of the components of the three lines represented in Figure 1 (Care, Salutogenesis, or Pedagogic Health) are stationary. These are not static points to aim for, but contours to travel along (Mazzei, 2017). All are constantly changing and developing as part of the 
wider teaching assemblage. Movements may take a colleague further from, or closer to, the central point (the triple point). In addition, each of these elements may be moving in different ways or at different speeds. However, these lines are not unrelated. For example, greater meaningfulness (salutogenesis) may be gained by scholarly exploration of the regulative discourse (pedagogic health, discourse). This exploration may be undertaken by engagement with professional development courses that are provided by developers to care about the development of teaching (care, receiving). We can therefore hypothesise various chains of events that might activate different elements represented in Figure 1 that might be channelling a colleague towards a realisation of their own triple point. Conversely, a colleague who is working in an environment where they do not feel cared for (care, lack of recognition); and who cannot make sense of their role in the institution (salutogenesis, comprehensibility); or of the regulations under which they have to work (pedagogic health, locus of control), is likely to feel overwhelmed by their work. The question then is, can colleagues recognise their trajectory towards a personal triple point, and are they able to articulate a personal cartography? This is not the same as achieving recognition through the acquisition of certificated competencies, but rather is about devising an adaptive pathway for continuing professional health in an environment that is unpredictable and changing. As these paths are anticipated to be entangled and highly interconnected, we have adopted a 'messy analysis' (sensu Koro-Ljunberg, 2016) to examine the fine-grained multiplicities of professional experiences, as opposed to exposing patterns and constricting regularities to form a thematic analysis.

\section{Articulating a collaborative cartography}

Taken from extensive conversations, the quotes selected below are indicators of a collaborative cartography. The individual illustrative comments are not attributed to particular participants. In addition, as we are looking particularly at the overlaps between key lines of flight (rather than how each line develops - as was the case in Kinchin, 2019), we consider the data as a singular 'messy assemblage' (sensu Mooney Simmie et al., 2019) or 'collective assemblage of enunciation' in which the assemblage is the unit of analysis (Mazzei, 2016). Within the conversations reported here, illustrated by short excerpts, colleagues talk about micro-moments of positive effect (sensu Gannon et al, 2019) with consistent regularity. These are usually spoken of as personal (even private) events rather than being provided by any sort of institutional recognition:

'it's just a couple of words make a big difference'

There is also a recognition that care is fragile, and negative attitudes can also be formed as quickly, often by minor acts of omission:

'it doesn't actually take very much for a student to then think, "wow, they obviously don't care"' 
This means that the caring environment needs constant monitoring and maintenance. It is also clear that an 'agenda for care' does not fit easily with the current pre-occupation for measurement or with the discourse of excellence that pervades higher education where, 'since excellence is a measure of a thing, and since everything in post-secondary education is committed to excellence, everything must be measured' (Saunders and Ramirez, 2017). As participants point out:

'we are negotiating what it is to be human. And how it is to communicate the human condition to other humans. You can't give that a number, but that can be a very tricky experience and a very exposing experience, day-in day-out in the classroom. And so we have to be full of care and kindness to one another when we are negotiating that on a minute by minute basis'.

Participants also emphasise the human connection and describe it as: 'more than just going into a classroom and delivering a session, and coming out, and feeling like I've done a good job. It's about trying to create some connections with people. Even if that's not on a one to one basis with absolutely everybody because, clearly, that's not always possible to do. But just some kind of interaction.'

Care is not about doing everything for the student to make life easy. Care is to do with providing students with challenge, not spoon -feeding them the answers:

In my experience [spoon-feeding] wasn't helping them at all, to be able to operate with resilience when things maybe didn't go the way they wanted it to go. The consumer model hasn't helped us, for sure, and the fact that universities now run themselves as businesses definitely doesn't help us at all.'

Participants' references to caring and being cared for are invariably entwined with other aspects of practice. Reference to aspects of the pedagogic health model would often appear with colleagues' commentaries. For example, the well-documented conflict between research and teaching (e.g. Hosein, 2017) is to be found entangled with comments about care:

'Heaven help you if your caring about the student experience has an impact on bringing in research funding or publishing papers'.

In addition, the teacher's proximity to the locus of control is clearly an important element of these colleagues' teaching satisfaction:

'I choose to focus on the aspects of my role that I really enjoy, but also the things that I have more control over. If you care too much about the wrong thing, especially the things you don't' have control over, that is the quickest way to real unhappiness.'

A sense of professional agency is also important, and deciding what not to care about and prioritising activities is a key aspect of self-care:

And when I start to feel overwhelmed, it's when I'm not doing that. And I'm thinking, oh my God, I've got all these things to do, and everybody wants this and that, and this is changing. And then, I have to just kind of step back and say, okay, well, this is what I'm going to do.' 
An awareness of the potential to become overwhelmed was evident when talking to all the participants:

'My son's got a phrase that I didn't even know... I don't know where he picked it up from. But when he was talking to his own school teacher he said that learning is like a waterfall. I know there's a path up the back to the top so I can dive off, but someone needs to take me up the path. And I just sat there and went wow! But actually, to me, that's exactly it. I'm there to signpost. I'm there to go 'come on, this way, this way'. I'm not there to dictate what that journey looks like. But I'm there to show the way of the journey and say 'come on'.'

It would seem that there is a hierarchy of care within higher education. Whilst we must care for our students (and been seen to care) this must not interfere with the institutional goals of research recognition. This resonates with what is referred to by Shields and Watermeyer (2020) as 'competing institutional logics', where differences between academics' understandings of 'the university' lead to antagonism and contradictory terms of reference. There are so many competing agendas and discourses within the university that may be a distraction from the 'here and now'. Participants talk about students 'enjoying and engaging and immersing themselves in the learning and in the experience of the learning', rather than worrying about how this will translate into grades or graduate attributes for employment. This resonates with Wang's $(2015,1556)$ view of the way in which we should invite students to 'lose the way' through the curriculum, rather than just follow a pre-given and well-trodden pathway. This would allow students to be able to explore their identity as a 'student', before having to consider the looming identity of a 'future worker' (O'Leary, 2017). That is not to say that that graduate employment is not important for teachers. Colleagues here were all concerned about their students' futures - as engineers, nurses or actors. But this is always in terms of a process of personal development rather than jumping through hoops to achieve certain grades.

It is clear that care is a reciprocal process and is perceived as such by the participants here. Students need to appreciate what it means to care for others and how it is perceived in everyday contexts. One participant explains how she gets students to make short presentations and then talks with them about the need to participate in class:

'why do you think that I, standing up here talking to you, got you to understand what the experience is like? They would go, well, I guess if the person who's listening to you isn't paying attention, then it's really difficult for you as the speaker to actually remain engaged. I said yes, so your learning experience is $50 \%$ within your gift to achieve. I promise you everyone that comes and lectures on this unit is really, really passionate about their topic area and they've worked really, really hard to think about how you're going to learn. But if you all sit there like stone mullets and give nothing back, what's going to happen to the person up here? You did that for two minutes each. They're doing it for two hours. They would learn that the whole learning experience is not just about what the teacher is doing in front of them, it's also about what they're doing, and what they're bringing into the room.' 


\section{The promise of empowerment}

Participants were asked to reflect on the conversations that underpinned the comments above, and to consider whether or not the promise of empowerment (as suggested by Gilmer, 2002) was realistic within their own contexts. It seems that the concept of 'becoming' might itself be liberating:

I find it very empowering, in the sense of gaining personal agency. For me, acknowledging that there is no terminal end point to chase releases me from a tick box, to do list treadmill. Knowing and naming the process itself as the central principle to my personal practice elevates and promotes the cyclical and helical role of reflection and progress. This keeps me in the place I ask my students to occupy, valuing progress and process over performance. I find that both the pull and synergy between these three aspects of my daily activity generate an energy and a drive that stimulates productivity.

The central idea of 'listening' (identified as key to the concept of care by Jung, 2016), was evident among the discussions:

For me, the whole purpose of me getting into academia was about the support and really caring about the students and as such, being able to participate in working groups and being involved in SSLC's and other forums where I am able to have an impact and actually listen to students and respond and create action plans in order to improve the learning experience has made my job not only more enjoyable, but re-emphasises the reason for me being in academia. I feel very supported. My relationship with the Head of Department is very good and I have always felt that my views are listened to and feel I am able to make decisions on behalf of other academics. The support offered by the University in terms of Development opportunities and free pedagogical development workshops, is fantastic.

The value of having a visualisation (Figure 1) to use as a reference point was valued by the participants:

I think I am a caring teacher - Figure 1 legitimises the importance of this. In terms of Salutogenesis I have learnt to balance work and home life and how to make my workload more manageable. Within HE there's almost a culture of one-upmanship in terms of who has the highest workload, works the most evenings, weekends. I think this is really unhealthy. I have enough insight and organisational skills to enable me to cope - but this is something I have had to learn. If I let myself get overwhelmed, I lose my ability to maintain my own health and well-being and cannot then care for myself or others.

Figure 1 helps me to recognise the need to balance these key issues, and also to help others recognise the need to do this - it's not enough to be kind and to care. I also need to manage health and well-being and my sense of purpose alongside my pedagogic health. These all overlap - reaching my triple point 
sometimes happens - these are transient moments which are easily destabilised - sadly the triple point is not sustainable at all times, but understanding this and what I need to do to move back towards it is enormously helpful.

The balance between empowerment and potential disempowerment is one that needs to be monitored as the competing voices and agendas within an institution can result in negative responses:

I believe that the university wishes its community to benefit from the outcomes of my productivity, but that key stakeholders in the recognition process do not always value or recognise the nature of the process over product approach. This can at the very least be disappointing, and at the most dis-empowering or disenfranchising. However, I do believe the students and my colleagues fully understand this approach and within my field there is considerable support and recognition to be found.

There is concern among academics that emphasis on a teaching identity within a research-intensive university represents a 'poisoned chalice' as it can lead to negative reactions from peers and managers that can lead to the side-lining of individuals (Skelton, 2013). This develops from a perception that those colleagues who are invested in teaching are simply pursuing private interests that are not conducive to the research focus of the department:

I think caring as part of our role, has not been given the recognition or been seen to be an important or essential part of the teachers' role in HEI (probably not part of the curriculum of any PGCert programme?). It is better to be known as someone who has a charismatic teaching style, be up to date with digital technologies etc., than a caring teacher. Caring does not carry the same status. I would like to think both students and staff consider me as someone who cares about what I do and about them as individuals. It is important to me that I am seen to care about our educational provision and the support we give each other. Legitimising the identity of a caring teacher gives me more confidence to say this is who I am/what I am good at - but fear this is not recognised or taken seriously by the wider academic community in the same way other attributes or skills are. This might also lead to disempowerment - caring on its own does not give you the authority or power to do something. The University does provide support for development, but only if as an individual you can identify your own learning needs, goals and aspirations and put things into place to meet these. I have had great support from line managers, but for some time I just worked harder and longer with no progress made in terms of my own development. It took me a number of years to recognise this and I needed to become more strategic in order to get promotion, for example. Nobody does that for you - once I realised this, I felt more empowered. 


\section{Discussion}

Despite the wealth of experience shared among those involved in this work, and the recognition they have gained for excellence in teaching from various quarters, none of the participants professed expertise in teaching. Participants used expressions such as 'I think I've got enough capacity to do an okay job and to get by.' As such, the language used is more aligned to the rhizomatic academic than the silo researcher (Table 1). Underpinning this seems to be an implicit self-image of the 'becoming teacher' (sensu Strom \& Martin, 2017; Adams, 2021). Despite being highly experienced and regarded by their peers as academic leaders, these colleagues still feel that they are learning about teaching. This personal view also appears to translate into their view of their students as dynamic and changing, and resonates with the perspective offered by Guyotte et al. $(2019,1)$ : 'as dynamic subjects, students are perpetually in motion, in transition, and in relation, which shifts our analysis from the fixity of being, to dynamic narratives of becoming in higher education', as well as the perspective offered by Osborne et al. (2020) of students as epistemological agents who need to be encouraged to use their 'life knowledge' alongside their academic knowledge. This is in contrast to the whole 'excellence' discourse that is seen to commodify academic practice as part of the neoliberal hegemonic agenda by focussing on static quantitative expressions of creative and dynamic educational processes as part of a simplistic governance by numbers (e.g. Sellar, 2015, Brink, 2018). Academics who maintain strong professional value and who challenge the status quo might be considered as 'subversives' - working counter to the prevailing currents in the system, engaged in 'acts of resistance' against the forces of neoliberalism (Tomlinson, et al. 2018). In rhizomatic terms (e.g. Strom \& Martin, 2017; Guerin, 2013), these academics are following disruptive 'lines of flight', in a constant, dynamic state of 'becoming' - an approach they might perceive to liberate their teaching from the neoliberal bonds that restrict and appraise their efforts, and which maintain an inertia in the evolution of institutional systems. It is hoped that the reflections offered here, and the framework summarised in Figure 1, will support similar reflections among colleagues to help them negotiate their own professional entanglements and the recognition of their own triple points and the constant movements and adjustments of the teaching assemblage that will be needed to keep it in sight. 
Table 1

A Comparison of Academic Identities: Silo Disciplines and Rhizomatic Cultures (after Guerin, 2013)

\begin{tabular}{ll}
\hline \multicolumn{1}{c}{ Silo discipline } & \multicolumn{1}{c}{ Rhizomatic culture } \\
\hline Expert & Always learning \\
Core content that is known & Open to new knowledge \\
Predictable content & Unknown material \\
Separate & Networked, connected \\
Lone researcher & Collaborative, collegial \\
Clear opinions & Tentative \\
Confident & Modest \\
Fixed, endpoint & Flexible, in-between \\
Homogeneous & Hetergeneous \\
Singularity, either/or & Multiplicity. both/and \\
Telling & (actively) listening \\
\hline
\end{tabular}

\section{Conclusions}

The cartography of caring teaching explored above is messy and complex (Mooney Simmie, et al., 2019). Attempts to simplify this messiness and to categorise the participants in this research will inevitably lose some of this complexity and lose the richness of the professional stories that are unfolding (Law, 2004). However, the process of cartography recognises the incompleteness and transitory nature of the data:

The principle of cartography implies that we can compare narrative selfhood with a dynamic map of narrations (and not with a tracing of reality), a map that is always open and always changing. The narrations someone tells about herself or himself are never complete; they form an ongoing process of co-construction and co-reconstruction. As a researcher, one can thus never have a view on the complete map of one's participant, seeing that this map is co-constructed, multiple, and constantly changing (Sermijn et al., 2008, 644).

These narratives are very personal, and it should be noted that dimensions of the becoming teacher explored above, such as 'being cared for', are determined as much by affective and subjective criteria as they are by objective, evidence-based criteria (Gannon et al., 2014). We therefore need to recognise the importance of understanding the rich ecology of knowledges that contribute to understanding (e.g. Santos, 2014), and the value of a perspective informed by epistemological pluralism that helps to combine and apply the appropriate frame of reference to the appropriate context (Andreotti et al., 2011). The consideration of teaching expertise within the context of Santos' Ecology of Knowledges 
brings to the fore the convergence between Santos' framework and professional knowledge. This has been explored particularly in the 'caring professions' (e.g. Lussi, 2020; Cassiano et al., 2021). The application of this view here to the caring-becoming-teacher allows us to value a more comprehensive and inclusive ecology of knowledges that contribute to teacher development so that participants do not feel there is a correct answer to be achieved. The development of personal narrative is therefore an active 'mapping' (sensu Deleuze and Guattari, 1987) to explore new ground, rather than a 'tracing' that can be placed against a number of preconceived criteria for assessment. As such, this offers a truly developmental tool for teachers, with no element of managerial evaluation remembering that the unit of analysis is the teaching assemblage.

\section{Recommendations}

Underpinning this work is the explicit recognition of a philosophy of becoming. While this may appear an alien concept to some observers at the outset, we have found here that an implicit philosophy of becoming already underpins colleagues' perceptions of their teaching, and may have a liberating function. The development of parallel states of becoming across the dimensions of the triple point helps to develop a degree of resilience. Where there may be conflicting perspectives of being and becoming there will be tensions that result in an environment that promotes pedagogic frailty (Kinchin and Gravett, 2021). University management, therefore, needs to consider how policies and directives can be reformed to be in tune with this philosophy. This will help to provide an environment in which colleagues may be empowered to approach their own triple points, to release the energy described above by Gilmer (2002). In summary, university management needs to have complementary strategies in place to:

1. Promote a sense of coherence that focuses on meaningfulness, manageability, and comprehensibility of the institution's policy patchwork.

2. Promote pedagogic health by considering the connections between the four components and how they may be developed (Kinchin and Winstone, 2017).

3. Promote a sense of care, starting with the notion of self-care.

These are complex issues and they need to be explored in dialogue with stakeholders. This work is continuing at this institution. 


\section{References}

Adams, E. (2021). Being before: three Deleuzian becomings in teacher education. Professional Development in Education, 1-14. https://doi.org/10.1080/19415257.2021.1891954

Andreotti, V., Ahenakew, C., \& Cooper, G. (2011). Epistemological pluralism: Ethical and pedagogical challenges in higher education. AlterNative, 7(1), 40-50. https://doi. org/10.1177/117718011100700104

Antonovsky, A. (1987). Unravelling the mystery of health: How people manage stress and stay well. San Francisco: Jossey Bass.

Arao, B., \& Clemens, K. (2013). From safe spaces to brave spaces: A new way to frame dialogue around diversity and social justice. In L. M. Landremann, (Ed.), The art of effective facilitation: Reflections from social justice educators (pp. 135-150). Sterling, VA, Stylus Publishing.

Aronsson, L., \& Lenz Taguchi, H. (2018). Mapping a collaborative cartography of the encounters between the neurosciences and early childhood education practices. Discourse: Studies in the Cultural Politics of Education, 39(2), 242-257. https://doi.org/10.1080/01596306.2017.1396732

Ball, S. J., \& Olmedo, A. (2013). Care of the self, resistance and subjectivity under neoliberal governmentalities. Critical Studies in Education, 54(1), 85-96. https://doi.org/10.1080/ 17508487.2013.740678

Brink, C. (2018). The soul of a university: Why excellence is not enough. Bristol: Bristol University Press.

Cassiano, A. D. N., Menezes, R. M. P. D., Medeiros, S. M. D., Silva, C. J. D. A., \& Lima, M. C. R. A. D. A. D. (2021). Performance of nurse-midwives from the perspective of Epistemologies of the South. Escola Anna Nery, 25(1), e20200057. https://doi.org/10.1590/21779465-ean-2020-0057

Charteris, J., Gannon, S., Mayes, E., Nye, A., \& Stephenson, L. (2016). The emotional knots of academicity: a collective biography of academic subjectivities and spaces. Higher Education Research \& Development, 35(1), 31-44. https://doi.org/10.1080/07294360.2015.1121209

Cristancho, S., \& Fenwick, T. (2015). Mapping a surgeon's becoming with Deleuze. Medical Humanities, 41(2), 128-135. http://dx.doi.org/10.1136/medhum-2015-010735

DeLanda, M. (2016). Assemblage theory. Edinburgh: Edinburgh University Press.

Deleuze, F., \& Guattari, F. (1987). A thousand plateaus (Trans. Massumi, B.). London, Bloomsbury.

Derham, C. (2018). Nursing. In I. M. Kinchin, \& N. E. Winstone, (Eds.), Exploring pedagogic frailty and resilience: Case studies of academic narrative (pp. 61-75). Leiden: Brill.

Eslahi, A., Chadeesingh, R., Foreman, C., \& Alpay, E. (2020). 3D printers in engineering education. In K. Gravett, N. Yakovchuk, I.M. Kinchin, (Eds.), Enhancing Student-Centred Teaching in Higher Education: The Landscape of Student-Staff Partnerships (pp. 97-112) Cham, Switzerland: Palgrave Macmillan.

Foreman, C. Hilditch, M., Rockliff, N., \& Clarke, H. (2020). A comparison of student perceptions of physical and virtual engineering laboratory classes. In: K. Gravett, N. Yakovchuk, \& 
I. M. Kinchin, (Eds.) Enhancing student-centred teaching in higher education: The landscape of student-staff partnerships (pp. 151-167). Cham, Switzerland: Palgrave Macmillan.

Gannon, S., Taylor, C., Adams, G., Donaghue, H., Hannam-Swain, S., Harris-Evans, J., Healey, J., \& Moore, P. (2019). 'Working on a rocky shore': Micro-moments of positive affect in academic work. Emotion, Space and Society, 31, 48-55. https://doi.org/10.1016/j.emospa.2019.04.002

Gannon, S., Walsh, S., Byers, M., \& Rajiva, M. (2014). Deterritorializing collective biography. International Journal of Qualitative Studies in Education, 27(2), 181-195. https://doi.org/10. 1080/09518398.2012.737044

Gilmer, P. J. (2002). Opalescence at the triple point: Research, teaching and service. In P. C., Taylor, P. J Gilmer, \& K. Tobin (Eds.), Transforming Undergraduate Science Teaching: Social Constructivist Perspectives. Counterpoints: Studies in the Postmodern Theory of Education (pp. 423-462). New York: Peter Lang Publishing. https://www.jstor.org/stable/42977050

Guerin, C. (2013). Rhizomatic research cultures, writing groups and academic research identities. International Journal of Doctoral Studies, 8, 137-150. http://ijds.org/Volume8/IJDSv8p137150Guerin0400.pdf

Guyotte, K. W. Flint, M. A., \& Latopolski, K. S. (2019). Cartographies of belonging: mapping nomadic narratives of first-year students, Critical Studies in Education. doi: $10.1080 / 17508487.2019 .1657160$

Hanratty, S., \& McNamara, A. (2020). Student experience: Perspectives on learning in the university and the conservatoire. In K Gravett, N. Yakovchuk, \& I. M. Kinchin (Eds.), Enhancing student-centred teaching in higher education: The landscape of student-staff partnerships (pp. 31-44). Cham, Switzerland: Palgrave Macmillan.

Hosein, A. (2017). Pedagogic frailty and the research-teaching nexus. In I. M. Kinchin, \& N. E. Winstone (Eds.), Pedagogic frailty and resilience in the university (pp. 135-149). Rotterdam: Sense.

Jung, J-H. (2016). The concept of care in curriculum studies: Juxtaposing currere and hakbeolism. London: Routledge.

Kinchin, I. M. (2019). Care as a threshold concept for teaching in the salutogenic university. Teaching in Higher Education. https://doi.org/10.1080/13562517.2019.1704726

Kinchin, I. M., \& Gravett, K. (2021). Dominant discourses in higher education: Critical perspectives, cartographies and practice. London: Bloomsbury.

Kinchin, I. M., \& Winstone, N. E. (Eds.). (2017). Pedagogic frailty and resilience in the university. Rotterdam: Sense.

Koro-Ljunberg, M. (2016). Reconceptualizing Qualitative Research: Methodologies without methodology. Thousand Oaks, CA: Sage.

Law, J. (2004). After method: Mess in social science research. London: Routledge.

Lenz Taguchi, H. (2016). Deleuzo-Guattarian rhizomatics: Mapping the desiring forces and connections between educational practices and the neurosciences. In C. A. Taylor, \& C. Hughes (Eds.), Posthuman research practices in education (pp. 37-57). NY: Palgrave Macmillan. 
Lussi, I. A. O. (2020). Social emancipation and occupational therapy: approaches from Epistemologies of the South and the ecology of knowledges. Cadernos Brasileiros de Terapia Ocupacional, 28(4), 1335-1345. https://doi.org/10.4322/2526-8910.ctoen2015

Manathunga, C., \& Bottrell, D. (2019). Prising open the cracks in neoliberal universities. In C. Manathunga, \& D. Bottrell, (Eds.), Resisting neoliberalism in higher education, 2 (pp. 1-22). Palgrave Critical University Studies.

Mårtensson, K., \& Roxå, T. (2015). Academic development in a world of informal learning about teaching and student learning. International Journal for Academic Development, 20, 109-112. https://doi.org/10.1080/1360144X.2015.1029736

Mazzei, L. A. (2016). Voice without a subject. Cultural Studies $\leftrightarrow$ Critical Methodologies, 16(2), 151-161. https://doi.org/10.1177/1532708616636893

Mazzei, L. A. (2017). Following the contour of concepts towards a minor inquiry. Qualitative Inquiry, 23(9), 675-685. https://doi.org/10.1177/1077800417725356

McCune, V. (2018). Experienced academics' pedagogical development in higher education: Time, technologies, and conversations. Oxford Review of Education, 44(3), 307-321. https:/doi.org/ 10.1080/03054985.2017.1389712

McNamara, A. (2018). Acting. In I. M. Kinchin, \& N. E. Winstone, (Eds.), Exploring pedagogic frailty and resilience: Case studies of academic narrative (pp. 151-168). Leiden: Brill.

Mooney Simmie, G., Moles, J., \& O'Grady, E. (2019). Good teaching as a messy narrative of change within a policy ensemble of networks, superstructures and flows. Critical Studies in Education, 60(1), 55-72. https://doi.org/10.1080/17508487.2016.1219960

Ng-A-Fook, N. (2005). A curriculum of mother-son plots on education's center stage. Journal of Curriculum Theorizing, 21(4), 43-58. https://search.proquest.com/scholarlyjournals/curriculum-mother-son-plots-on-educations-center/docview/194684178/ se2?accountid $=17256$

O'Leary, S. (2017). Graduates' experiences of, and attitudes towards, the inclusion of employabilityrelated support in undergraduate degree programmes; trends and variations by subject discipline and gender. Journal of Education and Work, 30(1), 84-105. https://doi.org/10.1080/ 13639080.2015.1122181

Osborne, E., Anderson, V., \& Robson, B. (2020). Students as epistemological agents: claiming life experience as real knowledge in health professional education. Higher Education, 1-16. https://doi.org/10.1007/s10734-020-00571-w

Panzieri, J., \& Durham, C. (2020). Student nurses' experiences of receiving verbal feedback within the clinical learning environment: to what extent does this promote sustainable feedback practices? In K. Gravett, N. Yakovchuk, \& I. M. Kinchin, (Eds.), Enhancing student-centred teaching in higher education: The landscape of student-staff partnerships. (pp. 237-253). Cham, Switzerland: Palgrave Macmillan.

Pinar, W. (2019). What is curriculum theory? (3rd. ed.) London: Routledge.

Querstret, D. (2019) Collaborating with students to support student mental health and wellbeing. In S. Lygo-Baker, I. M. Kinchin, \& N. E. Winstone, (Eds.), Engaging student voices in 
higher education: Diverse perspectives and expectations in partnership (pp. 191-207). Cham, Switzerland: Palgrave Macmillan.

Santos, B. de Sousa. (2014). Epistemologies of the South: Justice against epistemicide. London: Routledge.

Saunders, D. B., \& Ramirez, G. B. (2017). Against 'teaching excellence': ideology, commodification, and enabling the neoliberalization of postsecondary education. Teaching in Higher Education, 22(4), 396-407. https://doi.org/10.1080/13562517.2017.1301913

Sellar, S. (2015). A feel for numbers: affect, data and education policy. Critical Studies in Education, 56(1), 131-146. https://doi.org/10.1080/17508487.2015.981198

Sellers, W. (2008). Picturing currere towards c u ra: Rhizo-imaginary for curriculum. [PhD Thesis, Deakin University]. Australia: Melbourne. http://dro.deakin.edu.au/eserv/DU:30023301/ sellers-picturingcurrere-2008.pdf

Sermijn, J., Devlieger, P., \& Loots, G. (2008). The narrative construction of the self: Selfhood as a rhizomatic story. Qualitative inquiry, 14(4), 632-650. https://doi.org/10.1177/1077800408314356

Shields, R., \& Watermeyer, R. (2020). Competing institutional logics in universities in the United Kingdom: schism in the church of reason. Studies in Higher Education, 45(1), 3-17. https:// doi.org/10.1080/03075079.2018.1504910

Skelton, A. (2013). Positively transformational or poisoned chalice? The impact of a course on higher education teaching at a research-intensive institution. Teaching in Higher Education, 18(8), 908-919. https://doi.org/10.1080/13562517.2013.827640

Strom, K. J., \& Martin, A. D. (2017). Becoming-teacher: A rhizomatic look at first-year teaching. Rotterdam: Sense.

Taylor, C. A., Gannon, S., Adams, G., Donaghue, H., Hannam-Swain, S., Harris-Evans, J., Healey, J., \& Moore, P. (2020). Grim tales: Meetings, matterings and moments of silencing and frustration in everyday academic life. International Journal of Educational Research, 99, 101513. https://doi.org/10.1016/j.ijer.2019.101513

Tight, M. (2019). The neoliberal turn in higher education. Higher Education Quarterly, 73(3), 273-284. https://doi.org/10.1111/hequ.12197

Tomlinson, M., Enders, J., \& Naidoo, R. (2018). The teaching excellence framework: symbolic violence and the measured market in higher education. Critical Studies in Education. doi: 10.1080/17508487.2018.1553793

Zdebik, J. (2012). Deleuze and the diagram: Aesthetic threads in visual organization. London: Bloomsbury.

Žydžiūnaitè, V., \& Daugèla, M. (2020). Being a higher education teacher: Living in the professional space and creating the professional body. Pedagogika, 139 (3), 35-51. https://hdl.handle. net/20.500.12259/111541

Wang, C-L. (2015). Mapping or tracing? Rethinking curriculum mapping in higher education. Studies in Higher Education, 40(9), 1550-1559. https://doi.org/10.1080/03075079.2014.899343 


\title{
Salutogeninio universiteto tyrimas: trigubo taško tapsmas-globëjiškas-dèstytojas ieškojimas pasitelkiant bendradarbiavimo kartografiją
}

\author{
Ian M. Kinchin ${ }^{1}$, Cathrine Derham ${ }^{2}$, Charlotte Foreman ${ }^{3}$, Anna McNamara ${ }^{4}$, Dawn Querstret ${ }^{5}$ \\ Surejjaus universitetas, Surëjaus švietimo institutas, Gildfordas, GU2 7XH, JK, i.kinchin@surrey.ac.uk \\ Surèjaus universitetas, Sveikatos ir medicinos mokslų fakultetas, Gildfordas, GU2 7XH, JK, c.derham@surrey.ac.uk \\ Surejjaus universitetas, Inžinerijos ir fizikos mokslų fakultetas, Gildfordas, GU2 7XH, JK, c.foreman@surrey.ac.uk \\ Surëjaus universitetas, Gildfordo vaidybos mokykla, Gildfordas, GU2 7XH, JK, a.m.mcnamara@gsa.surrey.ac.uk \\ Šv. Marijos universitetas, Sveikatos, sporto ir taikomųjų mokslų fakultetas, Tvikenhamas, TW1 4SX, JK, \\ dawn.querstret@stmarys.ac.uk
}

\section{Santrauka}

Šiame straipsnyje, siekiant ịvertinti universiteto dėstytojų tobulëjimą, remiamasi Deleuze tapsmo filosofija. Didžiausias dėmesys skiriamas globejjiškumo kontekstui. Problema nagrinėjama remiantis keturių patyrusių mokslininkų, atskleidusių stiprią globėjiškumo komponentę savo profesiniame tapatume, nuomonėmis, formuojančiomis švietimo įstaigos kartografiją, kuri analizuojama platesne prasme, o ne remiantis atskirų dalyvių nuomonèmis. Pastebėta, kad globejiškumo kartografija susideda iš trijų raidos pertrūkio linijų, kurios identifikuojamos kaip globa, salutogenezè ir pedagoginè sveikata. Šių trijų komponentų suderinimas yra labai svarbus globejiško dèstytojo tobulejimui, nes tai konceptualizuojama kaip trigubo taško, kuriame minèti trys komponentai egzistuoja be ribų ar be sienų, formavimas. Šiame straipsnyje pateikiama šios koncepcijos vizualizacija ir buvo vertinama kaip parama dėstytojams, padedanti jiems suformuluoti savo profesinị kontekstą atsižvelgiant ị šią trigubą prasmę. Skirtingos žinios, kurias dėstytojai sujungia šiame procese, yra asmeniškos ir išskirtinès. Kritiškai reflektyvus dèstytoju globejjiškumo tyrinejjimas paremtas trigubo taško vizualizacija. Straipsnyje siūlomas metodas, kuris patyrusius universiteto dèstytojus gali paskatinti ieškoti savo profesinès veikmès bei atnaujinti požiūrị i dèstymą.

Esminiai žodžiai: asambliažas, tapsmas, globa, currere, pedagoginè sveikata, rizoma, salutogeneze.

Gauta 20210101 / Received 01012021

Priimta 20210317 / Accepted 17032021 